\title{
Zirconium-Doped Chromium IV Oxide Nanocomposites: Synthesis, Characterization, and Photocatalysis towards the Degradation of Organic Dyes
}

\author{
Zahir Muhammad ${ }^{1}$, Farman Ali ${ }^{1}$ (D), Muhammad Sajjad ${ }^{2}$, Nisar Ali ${ }^{3}$, Muhammad Bilal $^{4, *(D),}$ \\ Mohammed Rafi Shaik ${ }^{5, *(D)}$, Syed Farooq Adil ${ }^{5}\left(\mathbb{D}\right.$, Mohammed A.F. Sharaf ${ }^{6}$, Emad Mahrous Awwad ${ }^{7}$ \\ and Mujeeb Khan $5, *$ D
}

Citation: Muhammad, Z.; Ali, F. Sajjad, M.; Ali, N.; Bilal, M.; Shaik, M.R.; Adil, S.F.; Sharaf, M.A.F.; Awwad, E.M.; Khan, M.

Zirconium-Doped Chromium IV Oxide Nanocomposites: Synthesis, Characterization, and Photocatalysis towards the Degradation of Organic Dyes. Catalysts 2021, 11, 117. https://doi.org/10.3390/catal11010117

Received: 15 December 2020 Accepted: 11 January 2021 Published: 14 January 2021

Publisher's Note: MDPI stays neutral with regard to jurisdictional clai$\mathrm{ms}$ in published maps and institutional affiliations.

Copyright: $(\odot 2021$ by the authors. Licensee MDPI, Basel, Switzerland. This article is an open access article distributed under the terms and conditions of the Creative Commons Attribution (CC BY) license (https:// creativecommons.org/licenses/by/ $4.0 /)$
1 Department of Chemistry, Hazara University Mansehra, Dhodial 21300, Pakistan; zahirmuhammad82@gmail.com (Z.M.); farmanqau@gmail.com (F.A.)

2 Department of Physics, Kohat University of Science and Technology, Kohat 26000, Pakistan; sajjadqureshi76@gmail.com

3 Key Laboratory for Palygorskite Science and Applied Technology of Jiangsu Province, National \& Local Joint Engineering Research Center for Deep Utilization Technology of Rock-salt Resource, Faculty of Chemical Engineering, Huaiyin Institute of Technology, Huaian 223003, China; nisarali@hyit.edu.cn

4 School of Life Science and Food Engineering, Huaiyin Institute of Technology, Huaian 223003, China

5 Department of Chemistry, College of Science, King Saud University, P.O. Box 2455, Riyadh 11451, Saudi Arabia; sfadil@ksu.edu.sa

6 Department of Industrial Engineering, College of Engineering, King Saud University, P.O. Box 800, Riyadh 11421, Saudi Arabia; mfsharaf@ksu.edu.sa

7 Department of Electrical Engineering, College of Engineering, King Saud University, P.O. Box 800, Riyadh 11421, Saudi Arabia; 436107822@student.ksu.edu.sa

* Correspondence: bilaluaf@hyit.edu.cn (M.B.); mrshaik@ksu.edu.sa (M.R.S.); kmujeeb@ksu.edu.sa (M.K.); Tel.: +966-11-4670439 (M.R.S.)

Abstract: Degradation of organic dyes and their byproducts by heterogeneous photocatalysts is an essential process, as these dyes can be potentially discharged in wastewater and threaten aquatic and xerophyte life. Therefore, their complete mineralization into nontoxic components (water and salt) is necessary through the process of heterogeneous photocatalysis. In this study, $\mathrm{Zr} / \mathrm{CrO}_{2}$ (Zirconiumdoped chromium IV oxide) nanocomposite-based photocatalysts with different compositions (1, 3, 5 , $7 \& 9$ wt.\%) were prepared by an environmentally friendly, solid-state reaction at room temperature. The as-prepared samples were calcined under air at $450{ }^{\circ} \mathrm{C}$ in a furnace for a specific period of time. The synthesis of $\mathrm{Zr} / \mathrm{CrO}_{2}$ photocatalysts was confirmed by various techniques, including XRD, SEM, EDX, FT-IR, UV-Vis, and BET. The photocatalytic properties of all samples were tested towards the degradation of methylene blue and methyl orange organic dyes under UV light. The results revealed a concentration-dependent photocatalytic activity of photocatalysts, which increased the amount of dopant (up to 5 wt.\%). However, the degradation efficiency of the catalysts decreased upon further increasing the amount of dopant due to the recombination of holes and photoexcited electrons.

Keywords: zirconium dope chromium IV oxide; nanoparticles; photocatalytic degradation; UV/Vis spectroscopy; photocatalyst; methylene blue; methyl orange

\section{Introduction}

Water pollution is one of the major environmental issues that arises from the discharge of organic dyes in wastewater, which is a threat to both aquatic and human life [1]. Various methods used for the removal of these organic dyes from wastewater are reported in the literature [2], such as advanced oxidation, biological methods, and adsorption processes. [3] Among these methods, heterogeneous photocatalysis under UV light or artificial light is a popular choice [4]. In this regard, different types of metal and metal oxide nanoparticles 
(NPs) have gained significant attention as efficient photocatalysts. Compared to physical, chemical, and biological methods, dye degradation using NPs as photocatalysts offers various benefits, as NPs are effective, stable, inexpensive, easily prepared, and also possess efficient optical and electrical properties [5]. Among the various metal oxides, $\mathrm{CrO}_{2}$ has attracted great scientific interest in the fields of materials science and physical chemistry, since it is the only half-metallic (HM) ferromagnetic (FM) material in 3d transition metal dioxide form [6]. It offers various advantages, such as low cost [7], high thermal stability [8], and low toxicity [9]; thus, it can potentially be applied for the degradation of methylene blue [10] and methyl orange dyes [11]. However, the degradation ability of $\mathrm{CrO}_{2}$ is severely affected by its inability to fully absorb photons in the UV region; this is because of its large band gap (3.7 eV) [12]. In order to enhance the photo catalytic activity of $\mathrm{CrO}_{2}$ and reduce its band gap [6], it is typically doped with different types of noble metals, which creates defects and additional energy levels in its microstructure [13,14]. Thus far, various types of metals and their oxides have been used as dopants, including $\mathrm{Ru}$, Ti, and Sn [12,15].

Among the different elements, zirconium has been considered as an important material because of its various unique properties, which can be used for a number of applications. $\mathrm{Zr}$ doping in metal oxide (such as $\mathrm{CrO}_{2}$ ) nanoparticles produces many structural defects, e.g., interstitial defects and oxygen vacancies. The discussion of doping in this paper focuses on a solid solution obtained by combining a dopant $(\mathrm{Zr})$ and a host metal oxide $\left(\mathrm{CrO}_{2}\right)$, with the addition of oxygen. The charge of the $\mathrm{Zr}$ is then compensated for by an ionic defect that is gradually replaced by holes. When the equilibrium is disturbed as a result of the oxygen, the lattice defect is gradually replaced by electrons. The stoichiometric region of $\mathrm{CrO}_{2}$ is replaced by two regions: the byproduct of reduction, e.g., oxygen vacancies (electrons), and the byproduct of oxidation, e.g., cation vacancies (holes) in the region of higher oxygen vacancies [16]. Various authors have previously studied $\mathrm{Zr}$-doped metal oxides for the degradation of different dyes. Desta et al. studied $\mathrm{Zr}^{4+}$ doped $\mathrm{TiO}_{2}$ for the degradation of $\mathrm{MB}$ dye [17]. Khan et al. studied the effect of $\mathrm{Zr}$ doping in $\mathrm{CeO}_{2}$ for the degradation of $\mathrm{MB}$ dye [16]. Subash et al. investigated the effect of $\mathrm{Zr}$-loading on a Ag- $\mathrm{ZnO}$ composite for the degradation of red 120 dye [18]. Sulaiman et al. used $\mathrm{m}-\mathrm{ZrO}_{2}, \mathrm{c}-\mathrm{ZrO}_{2}$, and $\mathrm{t}-\mathrm{ZrO}_{2}$ for the degradation of $\mathrm{MO}$ dye [19]. Kumar et al. used ferromagnetic $\mathrm{ZrO}_{2}$ nanoparticles for the degradation of MB dye [20].

Chromium IV oxide can be used as a heterogeneous catalyst [9], and the dopant $\mathrm{Zr}$ can be used as a catalyst support [10,11], dielectric material [6], high-performance ceramic material [13] and in chemical sensors [15], solid oxide fuel cells [21,22], and as a photocatalyst [23]. It is a semiconductor metal oxide which is considered to be a suitable material because of its chemical and photochemical stability in aqueous medium. $\mathrm{Zr}$ doping of $\mathrm{CrO}_{2}$ not only enhances photocatalytic activity by increasing the surface area, but also stabilizes the structure at high temperature [21]; thus, the selective trapping of electrons occurs on $\mathrm{Zr}^{4+}$ in contrast to $\mathrm{Cr}^{4+}$ [22]. Therefore, the addition of a second element such as $\mathrm{Zr}$ enhances the thermal stability, increases the surface area of the host, and also helps to improve the separation rate of photo-induced electrons and holes. However, to the best of our knowledge, $\mathrm{Zr}$-doped $\mathrm{CrO}_{2}$ has been rarely reported as a photocatalyst for the degradation of dyes.

To date, various methods such as sol gel [23], coprecipitation [24], hydrothermal [25], sonication [26], ball mill [27], and flame pyrolysis [28] have been reported in the literature for the preparation of nanoparticle-based photocatalysts and their composites. However, such methods are often expensive, hazardous, and counterproductive to the fabrication of scalable and environmentally friendly composite materials. Therefore, in the current research, an eco-friendly, solid-state reaction [29] has been reported for the first time to prepare a Zr-doped, chromium IV oxide photocatalyst. In order to obtain an optimized dopant percentage, different samples were prepared by varying the amount of zirconium. The structure, morphology, and specific surface area of the as-prepared composites were investigated through X-ray diffraction, scanning electron microscopy, Brunauer-EmmettTeller (BET), and UV-visible absorption. Additionally, the band gaps of the synthesized 
$\mathrm{Zr} / \mathrm{CrO}_{2}$ materials were determined through diffused reflectance spectroscopy (DRS). Finally, photocatalytic experiments were carried out using the different samples under visible light.

\section{Results and Discussion}

\subsection{Structural and Morphological Characterization}

The prepared $\mathrm{Zr} / \mathrm{CrO}_{2}$ photocatalysts were characterized by their crystal structure, crystallite size, and phase composition by X-Ray diffraction technique. Figure $1 \mathrm{a}$ shows the XRD patterns of the synthesized $\mathrm{Zr} 1 \mathrm{CrO}_{2}, \mathrm{Zr} 3 \mathrm{CrO}_{2}, \mathrm{Zr} 5 \mathrm{CrO}_{2}, \mathrm{Zr} 7 \mathrm{CrO}_{2}$, and $\mathrm{Zr} 9 \mathrm{CrO}_{2}$ materials, which were tetragonal in structure and single phase due to the presence of (110), (101), (200), and (111) diffraction planes. The lattice parameters of $\mathrm{CrO}_{2}(\mathrm{a}=\mathrm{b}=4.421 \AA, \mathrm{c}=2.916 \AA)$ were almost similar to those of $\mathrm{TiO}_{2}(\mathrm{a}=\mathrm{b}=4.593 \AA, \mathrm{c}=2.959 \AA)$, which is considered an efficient photocatalyst [30]. When doping a metal, the size of the dopant is an important parameter. First, the dopant size should approximately match that of the host metal ( $\mathrm{Cr}$ or O). Second, if it is necessary to occupy the distance between the host atoms, an appropriately sized dopant is required; in the case of $\mathrm{Cr}-\mathrm{O}, \mathrm{Zr}$, has an atomic radius of $0.160 \mathrm{~nm}$. The $\left(4^{+}\right)$ ionic radius is $0.080 \mathrm{~nm}$ smaller than the distance between the $\mathrm{Cr}-\mathrm{O}$, which is $0.18 \mathrm{~nm}$ to $0.21 \mathrm{~nm}$. It is clear from the XRD pattern in Figure $1 \mathrm{~b}$ that the two most intensive peaks at (110) and (101) were slightly shifted towards the high angle (20) with low d-spacing after the incorporation of $\mathrm{Zr}$ in $\mathrm{CrO}_{2}$. This indicated that the $\mathrm{Cr}$ atoms had been replaced by $\mathrm{Zr}$ in the tetragonal structure of $\mathrm{CrO}_{2}$ due to substitution, which distorted the crystal structure of the host material on the basis of differences in the ionic radii of chromium and zirconium atoms [31,32]. The XRD pattern of $\mathrm{Zr} / \mathrm{CrO}_{2}$ showed few peaks of $\mathrm{Cr}_{2} \mathrm{O}_{3}$, which is considered to be one of the most stable oxides of chromium [33]; at high temperatures, $\mathrm{CrO}_{2}$ is converted to $\mathrm{Cr}_{2} \mathrm{O}_{3}$. The crystallite size obtained using the Scherrer equation [34] revealed an average size of the NPs of between $33.9 \mathrm{~nm}$ and $45 \mathrm{~nm}$. Notably, with varying zirconium doping from 1 to $9 \mathrm{wt} . \%$, the peak intensities also increased, along with the zirconium concentration.
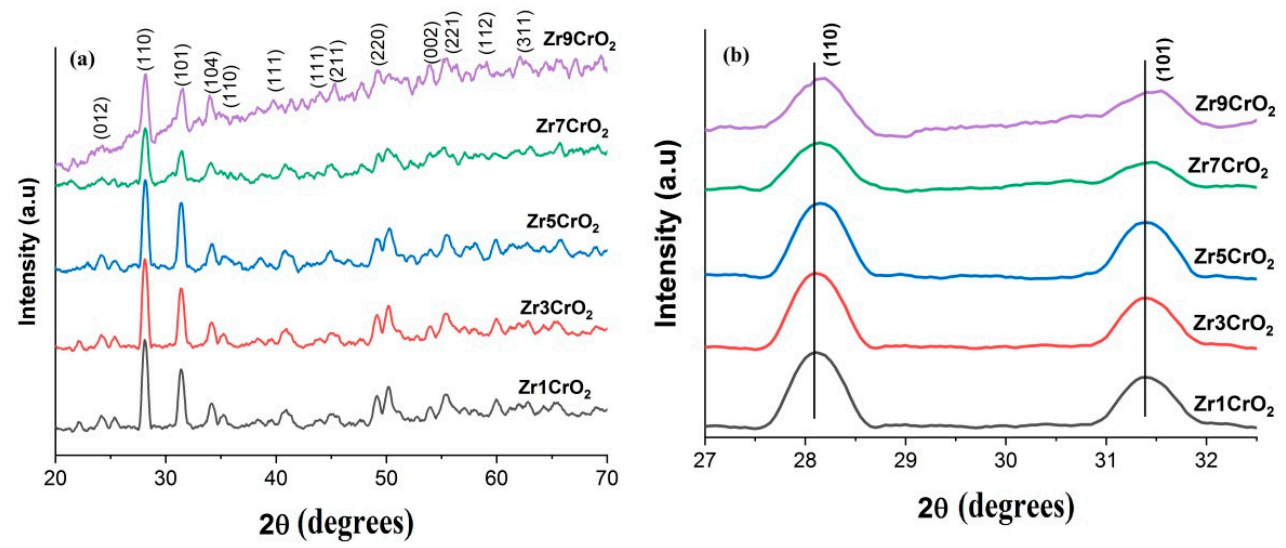

Figure 1. (a) Comparison of $\mathrm{XRD}$ spectra of $\mathrm{Zr} 1 \mathrm{CrO}_{2}, \mathrm{Zr} 3 \mathrm{CrO}_{2}, \mathrm{Zr} 5 \mathrm{CrO}_{2}, \mathrm{Zr} \mathrm{CrO}_{2}$, and $\mathrm{Zr} 9 \mathrm{CrO}_{2}$; (b) XRD spectra demonstrating peak shifts of (110) and (101) diffraction planes.

SEM was used for crystal morphology and shape observations of all the synthesized samples. The SEM images are shown in Figure 2. These images indicate that the shape and morphology of $\mathrm{Zr} / \mathrm{CrO}_{2}$ photocatalysts change with increasing $\mathrm{Zr}$ concentration. The particles seemed to agglomerate with an increase of $\mathrm{Zr}$ content and exhibit a flake shaped morphology, with average crystalline sizes of $33.9 \mathrm{~nm}$ to $45.3 \mathrm{~nm}$. The particles were dispersed properly in all samples, which is evident in Figure 2. To determine the elemental composition of all the samples, EDX was used, as shown in Figure 3. The EDX analysis showed that the material was in pure form with no elemental impurities present in the samples, while the concentration of $\mathrm{Zr}$ increased gradually. 

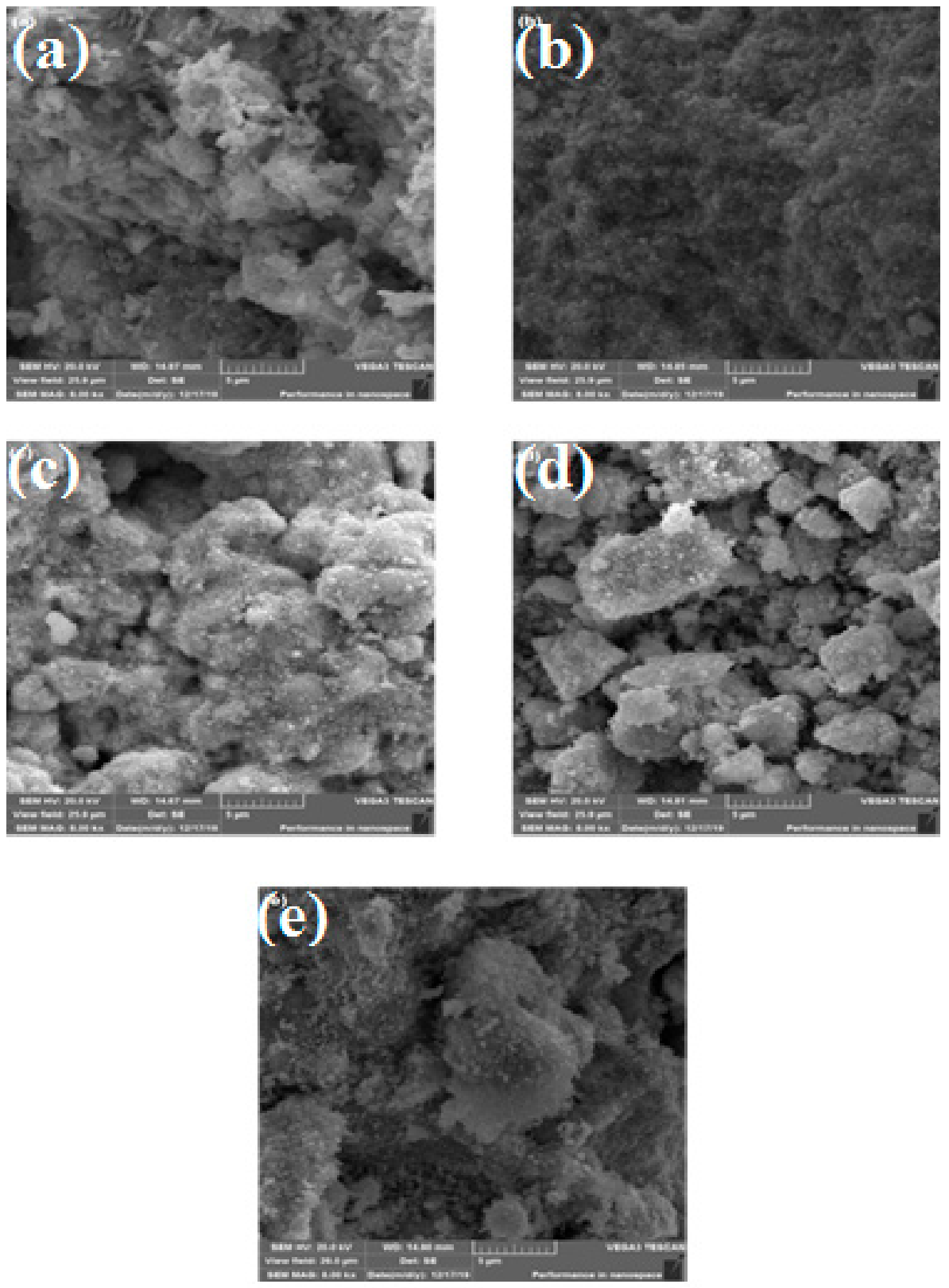

Figure 2. SEM images of (a) $\mathrm{Zr}_{1} \mathrm{CrO}_{2}$, (b) $\mathrm{Zr}_{3} \mathrm{CrO}_{2}$, (c) $\mathrm{Zr} 5 \mathrm{CrO}_{2}$, (d) $\mathrm{Zr} \mathrm{CrO}_{2}$, and (e) $\mathrm{Zr} 9 \mathrm{CrO}_{2}$ photocatalysts.

In order to further confirm the synthesis of all as-prepared $\mathrm{Zr} / \mathrm{CrO}_{2}$-based photo catalysts, FTIR spectra were measured, as shown in Figure 4 and Table 1. After calcinations, the synthesized photocatalysts were free from impurities and moisture. The IR spectra exhibited peaks at 3100, 3010, and $1986 \mathrm{~cm}^{-1}$ belonging to $\mathrm{C}-\mathrm{H}, \mathrm{C}-\mathrm{C}$, and $\mathrm{C}=\mathrm{O}$ functional groups. The peaks at 3400 and $1239 \mathrm{~cm}^{-1}$ represented $\mathrm{O}-\mathrm{H}$ and $\mathrm{C}-\mathrm{O}$ functional groups [35]. Different modes of vibration of $\mathrm{CrO}_{2}$ and $\mathrm{Zr}-\mathrm{O}$ were also visible in the IR spectra. For instance, the presence of $\mathrm{Zr}-\mathrm{O}$ was represented by the vibrational mode at $815 \mathrm{~cm}^{-1}$, while the peaks at 503 and $428 \mathrm{~cm}^{-1}$ corresponded to the vibration of $\mathrm{Cr}^{18} \mathrm{O}^{18} \mathrm{O}$ and $\mathrm{Cr}^{16} \mathrm{O}_{2}$, the peaks at 1110 and $653 \mathrm{~cm}^{-1}$ possibly pointed to the vibrational mode of $\mathrm{Cr}-\mathrm{O}$ and $\mathrm{O}-\mathrm{O}$ in $\mathrm{CrOO}$, and the vibrational mode of $\mathrm{O}-\mathrm{Cr}-\mathrm{O}$ appeared at $1789 \mathrm{~cm}^{-1}$ [36]. The stretching vibrational peak at $815 \mathrm{~cm}^{-1}$ indicated the presence of $\mathrm{Zr}-\mathrm{O}$ [37]. 

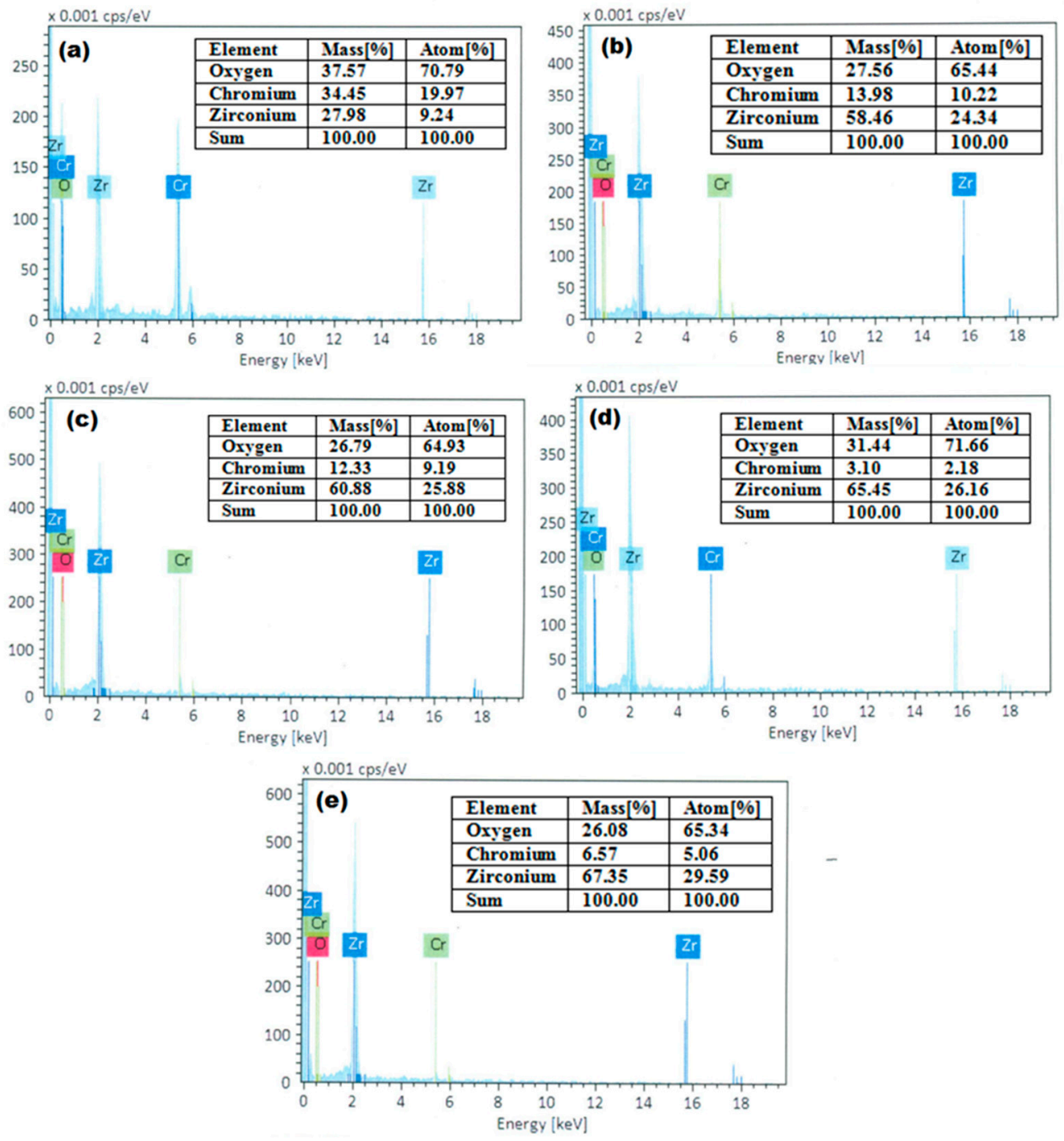

Figure 3. EDX spectra of (a) $\mathrm{Zr} 1 \mathrm{CrO}_{2}$, (b) $\mathrm{Zr}_{3} \mathrm{CrO}_{2}$, (c) $\mathrm{Zr} \mathrm{CrO}_{2}$, (d) $\mathrm{Zr}_{\mathrm{CrO}}$, and (e) $\mathrm{Zr9} 9 \mathrm{CrO}_{2}$ photocatalysts.

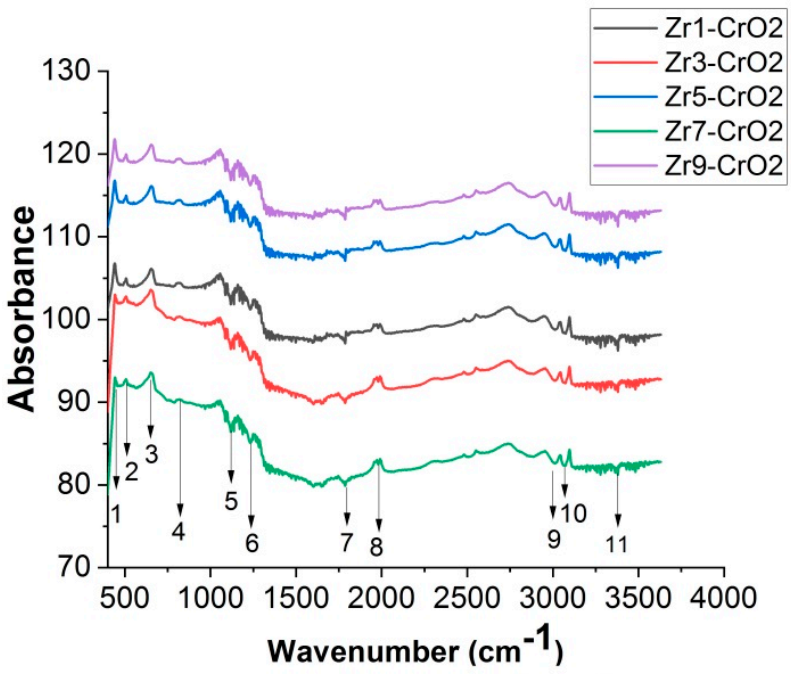

Figure 4. The FT-IR spectra of $\mathrm{Zr}$-doped $\mathrm{CrO}_{2}$ photocatalysts. 
Table 1. FT-IR studies of $\mathrm{Zr}$-doped $\mathrm{CrO}_{2}$ photocatalysts.

\begin{tabular}{cccc}
\hline Peak Number & Functional Group & Peak Position $\mathbf{~ c m}^{-\mathbf{1}}$ & Mode \\
\hline 1 & $\mathrm{Cr}^{16} \mathrm{O}_{2}$ & 428 & Stretching \\
\hline 2 & $\mathrm{Cr}^{18} \mathrm{O}^{18} \mathrm{O}$ & 503 & Stretching \\
\hline 3 & $\mathrm{CrOO}(\mathrm{O}-\mathrm{O})$ & 653 & Stretching \\
\hline 4 & $\mathrm{Zr}-\mathrm{O}$ & 815 & Bending \\
\hline 5 & $\mathrm{Cr}-\mathrm{O}$ & 1110 & Stretching \\
\hline 6 & $\mathrm{C}-\mathrm{O}-\mathrm{C}$ & 1239 & Stretching \\
\hline 7 & $\mathrm{O}^{52} \mathrm{CrO}$ & 1789 & Bending \\
\hline 8 & $\mathrm{CO}$ & 1986 & Bending \\
\hline 9 & $\mathrm{C}-\mathrm{C}$ & 3010 & Bending \\
\hline 10 & $\mathrm{C}-\mathrm{H}$ & 3100 & Vibration \\
\hline 11 & $\mathrm{OH}$ & 3400 & Stretching \\
\hline
\end{tabular}

The as-prepared $\mathrm{Zr} / \mathrm{CrO}_{2}$ photocatalysts $\left(\mathrm{Zr} 1 \mathrm{CrO}_{2}, \mathrm{Zr} 3 \mathrm{CrO}_{2}, \mathrm{Zr} 5 \mathrm{CrO}_{2}, \mathrm{Zr} \mathrm{CrO}_{2}\right.$, and $\mathrm{Zr9} \mathrm{CrO}_{2}$ ) were also investigated for absorption in the $200-800 \mathrm{~nm}$ wavelength region, as shown in Figure 5a. Pure $\mathrm{CrO}_{2}$ absorbance peaks appeared at $257 \mathrm{~nm}$ and $346 \mathrm{~nm}$ [33]; however, after doping, the absorbance peaks shifted to a higher wavelength [38]. For band gap studies, the Diffuse Reflectance Spectroscopy (DRS) technique was used. From the DRS spectra, the band gap of the as-prepared photocatalysts was calculated using the Tauc, Davis and Mott relation, given by $(\alpha \mathrm{h} v) 1 / 2=\mathrm{A}(\mathrm{h} v-\mathrm{Eg})$, where $\alpha, v, \mathrm{~A}$, and Eg are the absorption coefficient, light frequency, proportionality constant, and band gap, respectively [39-41]. From the plot for $(\alpha h v) 1 / 2$ vs. energy $(h v)$ shown in Figure $5 b$, the band gap could be evaluated by extrapolating the straight line to the axis intercept. By using the DRS technique, followed by the numerical relation given above, the band gaps of all the samples were calculated. The DRS studies of the prepared material showed band gaps of 4.3, 3.2, 2.9, 2.87, 2.7, and $2.4 \mathrm{eV}$ for pristine $\mathrm{CrO}_{2}, \mathrm{Zr} 1 \mathrm{CrO}_{2}, \mathrm{Zr} 3 \mathrm{CrO}_{2}, \mathrm{Zr5} \mathrm{CrO}_{2}$, $\mathrm{Zr} 7 \mathrm{CrO}_{2}$, and $\mathrm{Zr9CrO}$, respectively, as shown in Table 2. The DRS study revealed that after doping, the band gap decreased from $4.3 \mathrm{eV}$ to $2.4 \mathrm{eV}$, which made the samples capable of absorbing light in the UV region, ultimately enhancing their photocatalytic degradation capabilities.
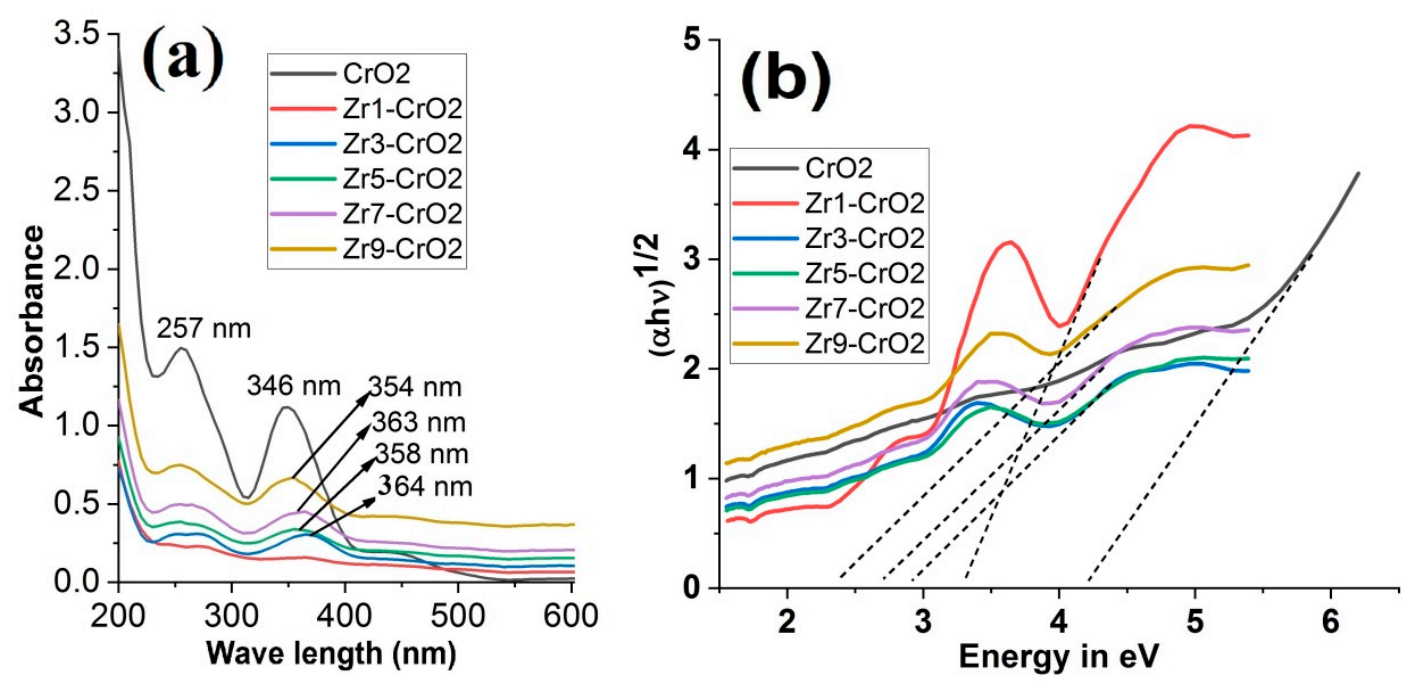

Figure 5. (a) UV-Vis spectra; (b) Band gaps of $\mathrm{Zr}$-doped $\mathrm{CrO}_{2}$ photocatalysts. 
Table 2. Band gaps of synthesized $\mathrm{Zr}$-doped $\mathrm{CrO}_{2}$ photocatalysts.

\begin{tabular}{ccccccc}
\hline Samples & $\mathrm{CrO}_{2}$ & $\mathrm{Zr1CrO}_{2}$ & $\mathrm{Zr} 3 \mathrm{CrO}_{2}$ & $\mathrm{Zr5CrO}_{2}$ & $\mathrm{Zr7CrO}_{2}$ & $\mathrm{Zr9CrO}_{2}$ \\
\hline Band gap (E) eV & 4.3 & 3.2 & 2.9 & 2.87 & 2.7 & 2.4 \\
\hline
\end{tabular}

BET was employed to determine the surface area and pore size of the prepared material. The results, shown in Table 3, indicated that by increasing the doping concentration of zirconium in chromium IV oxide, the surface area of the host metal oxide $\left(\mathrm{CrO}_{2}\right)$ also increased, which indicated that the maximum loading of the dopant and the degradation capacity of the material had been enhanced due to the large surface area, as shown [42].

Table 3. BET analysis of $\mathrm{Zr}$-doped $\mathrm{CrO}_{2}$ photocatalysts.

\begin{tabular}{ccc}
\hline Samples & Pore Size $\left(\mathbf{c m}^{3} / \mathbf{g}\right)$ & BET S.A. $\left(\mathbf{m}^{2} / \mathbf{g}\right)$ \\
\hline $\mathrm{Zr} 1 \mathrm{CrO}_{2}$ & 4.8 & 3.5 \\
\hline $\mathrm{Zr3CrO} 2$ & 12 & 8.7 \\
\hline $\mathrm{Zr} 5 \mathrm{CrO}_{2}$ & 13.4 & 9.9 \\
\hline $\mathrm{Zr7CrO} 2$ & 11.1 & 8.1 \\
\hline $\mathrm{Zr} 9 \mathrm{CrO}_{2}$ & 11.2 & 8.2 \\
\hline
\end{tabular}

\subsection{Studies of $\mathrm{Zr} / \mathrm{CrO}_{2}$ Photo-Catalysts for the Degradation of Dyes}

\subsubsection{The Degradation Study of MB and MO Dyes}

Both $\mathrm{MB}$ and $\mathrm{MO}$ are heterocyclic aromatic compounds, which are also known as azo dyes bearing the functional group $(\mathrm{R}-\mathrm{N}=\mathrm{N}-\hat{\mathrm{R}})$. Both $\mathrm{R}$ and $\mathrm{R}$ are aryl groups that can be degraded using $\mathrm{OH}$ radicals produced by metal-doped metal oxide nanoparticles that are activated by UV light in the presence of aqueous media, producing carbon dioxide, water, and minerals as byproducts. These dyes are known to alter the physicochemical properties of soil and poison water bodies, and can cause serious damage to the flora and fauna in the environment. The UV-visible spectroscopic technique was used to study the effect of dopant concentration and time during the degradation of methylene blue (MB) and methyl orange (MO) in aqueous media in the presence of catalysts. During the experiments, the concentrations both of dyes (MB and $\mathrm{MO}$ ) and photocatalysts were kept constant. The mixtures were prepared by dissolving $0.2 \mathrm{~g}$ of photocatalysts in $50 \mathrm{~mL}$ aqueous solution of each dye; before placing them under UV-light irradiation, these mixtures were kept in a dark place for $20 \mathrm{~min}$ to achieve complete adsorption and desorption equilibrium. The zero-time readings were taken, and the mixtures were studied under UV-light from $0-140 \mathrm{~min}$.

The photocatalytic experiments showed that as the dopant concentration increased, the efficiency of the photocatalyst also increased. However, this trend was followed only up to $5 \mathrm{wt} . \%$. After further increasing the amount of dopant, the efficiency of the samples dropped; this was due to the recombination of photoexcited electrons and holes and the energy absorbed by electrons during excitation that were released in the form of radiation [43]. The photocatalysts showed maximum efficiency from $1 \mathrm{wt} . \%$ to $5 \mathrm{wt} . \%$, beyond which the efficiency decreased for the $\mathrm{Zr} 7 \mathrm{CrO}_{2}$ and $\mathrm{Zr} 9 \mathrm{CrO}_{2}$ samples. This fact can be clearly seen from the UV/Visible degradation study of $\mathrm{MB}$ and MO dyes. Initially, the degradation rates of $\mathrm{MB}$ and $\mathrm{MO}$ dyes were fast due to high concentration of dye molecules; however, the rate decreased gradually due to the deficiency of dye molecules $[44,45]$. The effect of contact time and dopant concentration on catalysts with MB and MO dyes are shown in Figures 6 and 7, respectively, which indicate that by increasing the time, the catalytic efficiency also increases up to $140 \mathrm{~min}$. 

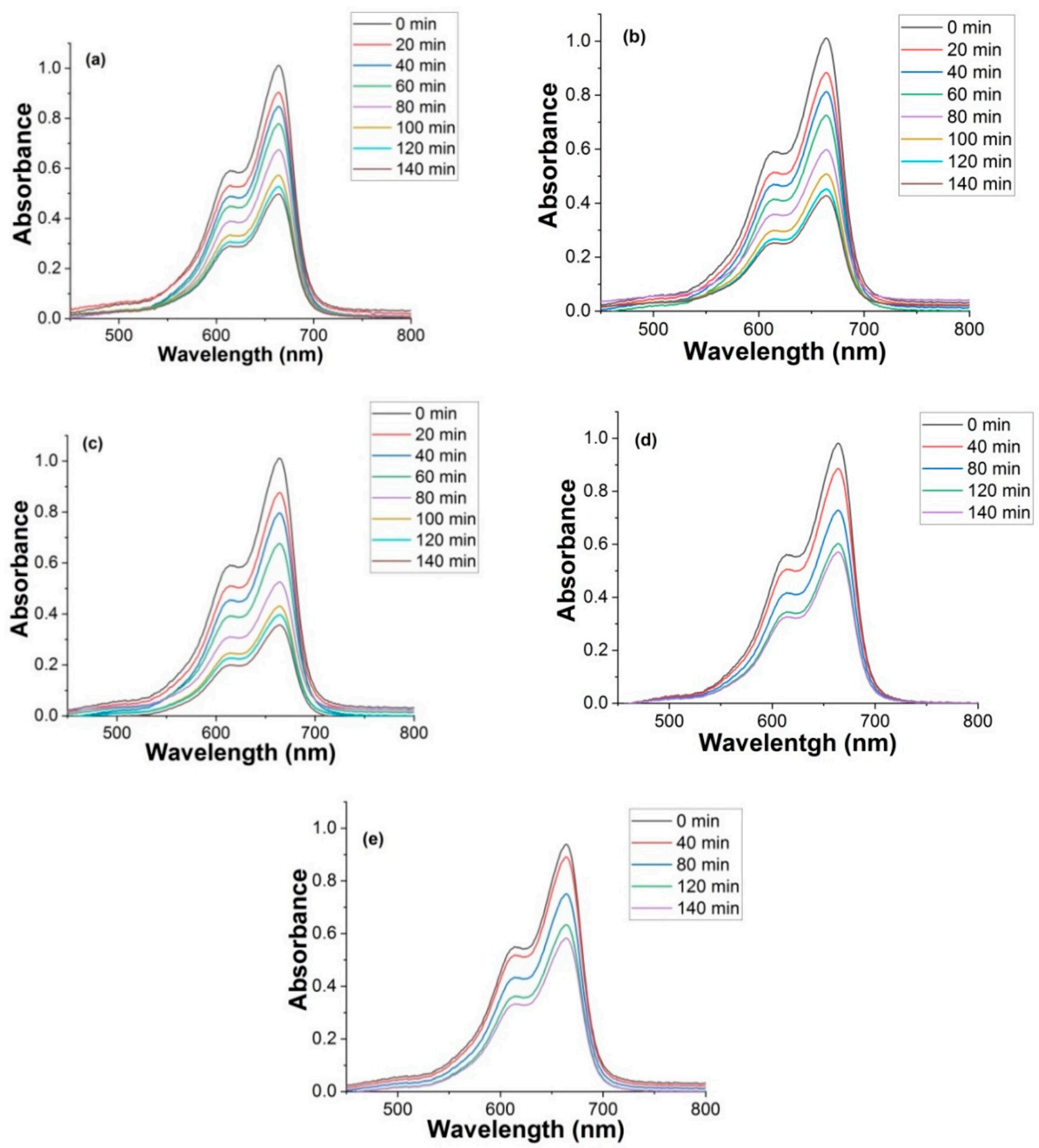

Figure 6. (a) $\mathrm{Zr}_{1} \mathrm{CrO}_{2}$, (b) $\mathrm{Zr}_{3} \mathrm{CrO}_{2}$, (c) $\mathrm{Zr}_{5} \mathrm{CrO}_{2}$, (d) $\mathrm{Zr}_{7} \mathrm{CrO}_{2}$, and (e) $\mathrm{Zr}_{\mathrm{CrO}}$ degradation of MB dye vs. contact time. 

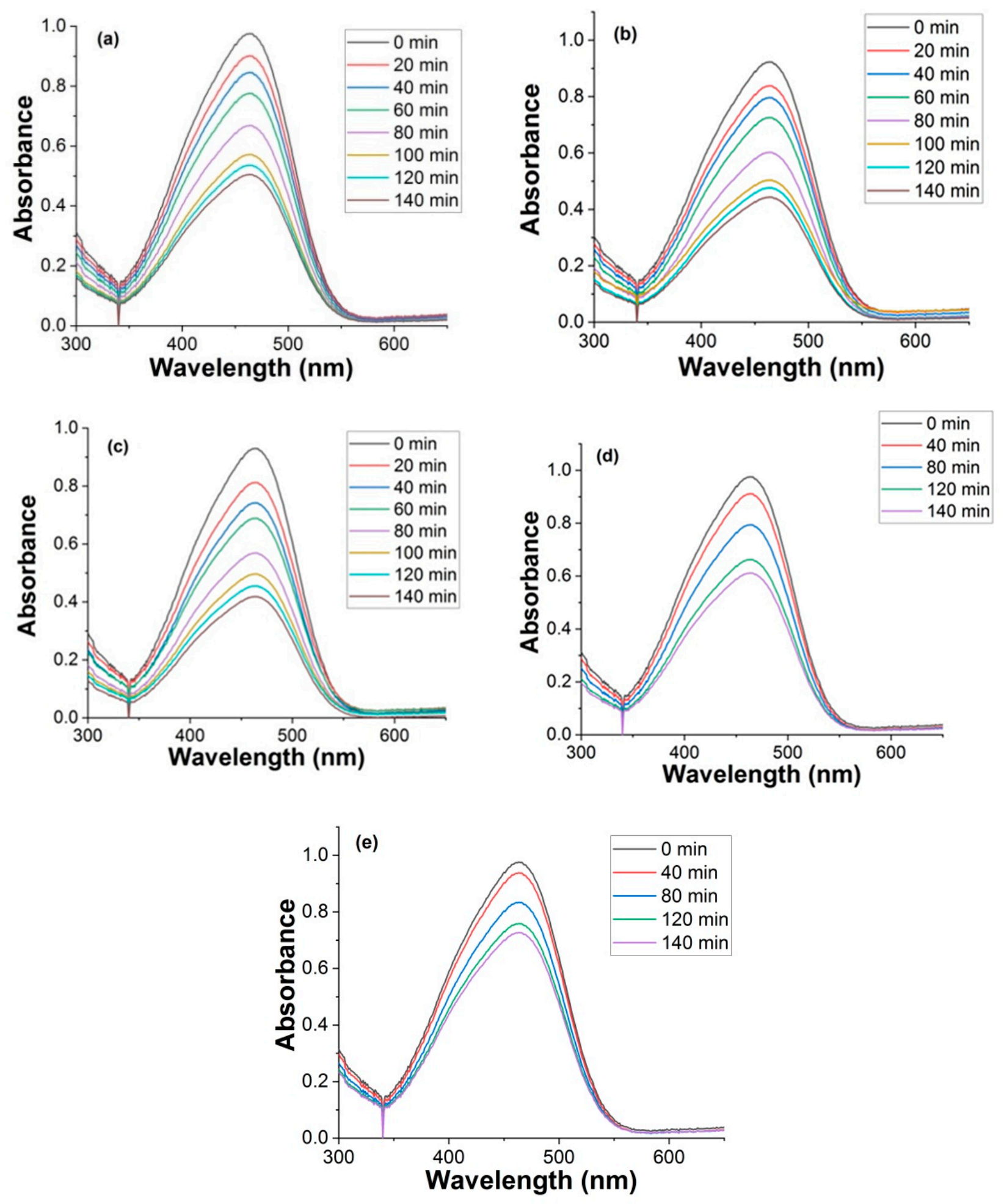

Figure 7. (a) $\mathrm{Zr} 1 C r O_{2}$, (b) $\mathrm{Zr}_{3} \mathrm{CrO}_{2}$, (c) $\mathrm{Zr}_{5} \mathrm{CrO}_{2}$, (d) $\mathrm{Zr}_{7} \mathrm{CrO}_{2}$, and (e) $\mathrm{Zr} 9 \mathrm{CrO}_{2}$ degradation of $\mathrm{MO}$ dye vs. contact time.

\subsubsection{The MB and MO Kinetic Study}

The reaction (degradation) kinetics of both $\mathrm{MB}$ and $\mathrm{MO}$ were studied by placing the prepared mixtures under UV-light for different intervals of time, i.e., 0-140 $\mathrm{min}$. The initial rate $\left(r_{0}\right)$ of degradation of methylene blue and methyl orange increased for $\mathrm{Zr} \mathrm{CrO}_{2}$, $\mathrm{Zr} 3 \mathrm{CrO}_{2}$, and $\mathrm{Zr} 5 \mathrm{CrO}_{2}$ as the concentration of zirconium increased, while the initial 
rate $\left(r_{0}\right)$ decreased in the case of $\mathrm{Zr} 7 \mathrm{CrO}_{2}$ and $\mathrm{Zr9} 9 \mathrm{CrO}_{2}$ due to the recombination of photoexcited electrons and holes. The Langmuir-Hinshelwood model can be used to understand the kinetics of photocatalytic degradation of MB and MO dyes as [46,47]:

$$
r_{0}=-\frac{d_{c}}{d_{t}}=\frac{k K_{c}}{1+K C}
$$

where $r_{0}$ denotes the initial reaction rate $\left(\mathrm{mg} \mathrm{L}^{-1} \mathrm{~min}^{-1}\right), C$ represents the dye concentration $\left(\mathrm{mg} \mathrm{L}^{-1}\right)$, and $t$ represents the reaction time $(\mathrm{min})$. In addition, $k$ and $K c$ represent the Langmuire-Hinshelwood reaction rate constant $\left(\mathrm{mg} \mathrm{L}^{-1} \mathrm{~min}^{-1}\right)$ and langmuire adsorption equilibrium constant $\left(\mathrm{L} \mathrm{mg}^{-1}\right)$. For small amounts of pollutants $(K C<<1)$, pseudo-firstorder kinetics can be applied, as given by the following equations:

$$
\begin{gathered}
r_{0}=-\frac{d_{c}}{d_{t}}=-k K C \\
\ln \frac{C_{0}}{C}=k K t=k_{a p p} t
\end{gathered}
$$

where apparent constant $\left(k_{a p p}\right)$ is the kinetics parameter, and $C_{0}$ and $C$ are initial and residual concentrations of $\mathrm{MB}$ and $\mathrm{MO}$ dyes in the aqueous phase before and after light irradiation, respectively. The $\left(k_{a p p}\right)$ can be found from $\left(\ln \frac{C_{0}}{C}\right)$ vs. irradiation time. For all photocatalysts, the initial degradation rates $\left(r_{0}=k_{a p p} \times C_{0}\right)$ of $10 \mathrm{mg} \mathrm{L}^{-1} \mathrm{MB}$ and $\mathrm{MO}$ were calculated, and the results are shown in Figure 8a,b, respectively.

To find the rate of degradation of $\mathrm{MB}$ and $\mathrm{MO}$ dyes, the pseudo first order kinetics can be applied, as given by the following equation as [48]:

$$
\frac{\ln C_{0}}{C_{t}}=K t
$$

where $C_{0}$ represents the initial concentration before irradiation, $C_{t}$ represents the concentration after irradiation, $t$ represents the time of irradiation, and $K$ is a constant which can be found as a slope after plotting, as shown in Figure 9a,b.

The photocatalytic efficiency of the prepared catalysts is dependent on the concentration of dopant $\left(\mathrm{Zr}^{4+}\right)$ in $\left(\mathrm{CrO}_{2}\right)$ nanoparticles. As the concentration of the dopant increases, the photocatalytic efficiency also increases up to $5 \mathrm{wt} . \%$, whereas for $7 \mathrm{wt} . \%$ and $9 \mathrm{wt} . \%$, the catalytic efficiency decreases due the recombination of holes and photoexcited electrons. The dopant enhanced the photocatalytic efficiency of the host materials due to the presence of $\left(\mathrm{Zr}^{4+}\right)$ ions, which gain electrons during photo-excitation by converting to $\left(\mathrm{Zr}^{3+}\right)$, which is transferred to $\mathrm{O}_{2}$ generating superoxide radical $\mathrm{O}_{2}{ }^{\bullet-}$, preventing photo-corrosion.
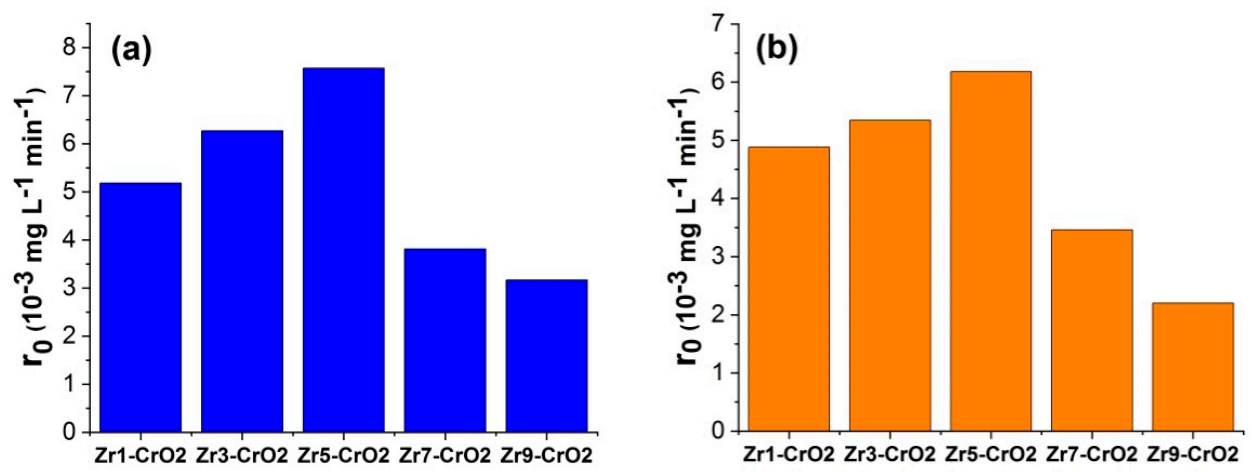

Figure 8. (a) Methylene blue and (b) Methyl orange initial rate $\left(r_{0}\right)$. 

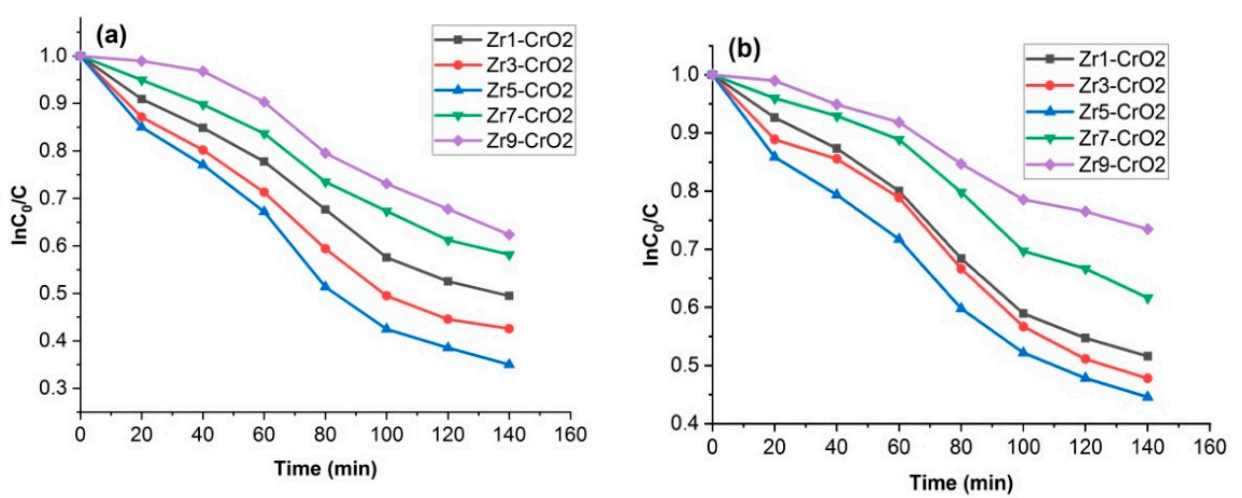

Figure 9. Photocatalytic degradation curve of (a) Methylene blue (b) Methyl orange.

2.2.3. $\mathrm{MB}$ and $\mathrm{MO}$ Percent Photo Catalytic Degradation Curve of $\mathrm{Zr}$-doped $\mathrm{CrO}_{2}$ as Function of time

To study the effects of contact time and dopant concentration on the percent degradation of $\mathrm{MB}$ and $\mathrm{MO}, 10 \mathrm{ppm}\left(\frac{10 \mathrm{mg}}{\mathrm{L}}\right)$ dye solutions were prepared in deionized water. The amount of prepared catalysts and dyes (MB and $\mathrm{MO}$ ) were kept constant. The efficiencies of the prepared photocatalysts varied for different dopant concentrations. The MB dye was degraded up to $50.5 \%, 57.4 \%$, and $64.4 \%$ by $\mathrm{Zr} 1 \mathrm{CrO}_{2}, \mathrm{Zr} 3 \mathrm{CrO}_{2}$, and $\mathrm{Zr} 5 \mathrm{CrO}_{2}$ photocatalysts after $140 \mathrm{~min}$, respectively, whereas $41.8 \%$ and $37.6 \%$ of $\mathrm{MB}$ dye was degraded by $\mathrm{Zr}_{7} \mathrm{CrO}_{2}$ and $\mathrm{Zr} 9 \mathrm{CrO}_{2}$, respectively (see Figure 10a,b). In the case of $\mathrm{MO}$ degradation, photocatalysts followed the same pattern as above. The MO dye was degraded up to $48.4 \%, 52.2 \%$, and $55.4 \%$ by $\mathrm{Zr} 1 \mathrm{CrO}_{2}, \mathrm{Zr} 3 \mathrm{CrO}_{2}$, and $\mathrm{Zr} 5 \mathrm{CrO}_{2}$ photocatalysts, respectively, after $140 \mathrm{~min}$, whereas $38.3 \%$ and $26.5 \%$ of $\mathrm{MO}$ dye degraded by $\mathrm{Zr} 7 \mathrm{CrO}_{2}$ and $\mathrm{Zr} 9 \mathrm{CrO}_{2}$ respectively (see Figure 11a,b). On the basis of percentage of degradation of $\mathrm{MB}$ and $\mathrm{MO}$ dyes, it is clear that after $5 \mathrm{wt}$ \% doping, the photocatalytic efficiency did not increase, because the doping crossed the optimum level; as a result, the electrons and holes were recombined, also known as photo-corrosion [49].
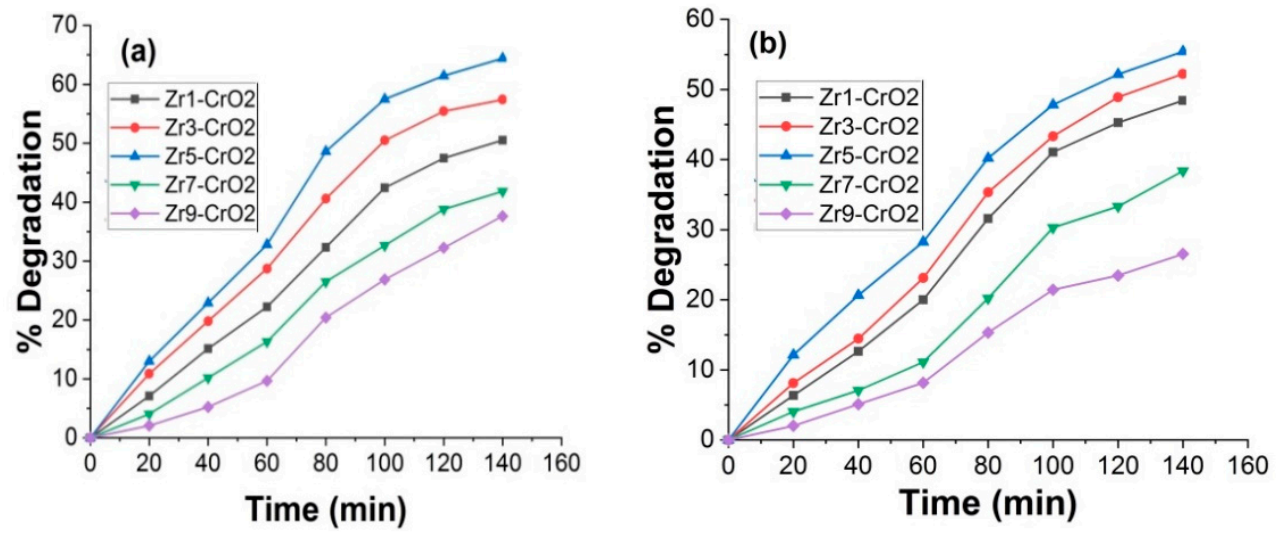

Figure 10. (a) Methylene blue (b) Methyl orange percent photocatalytic degradation. 

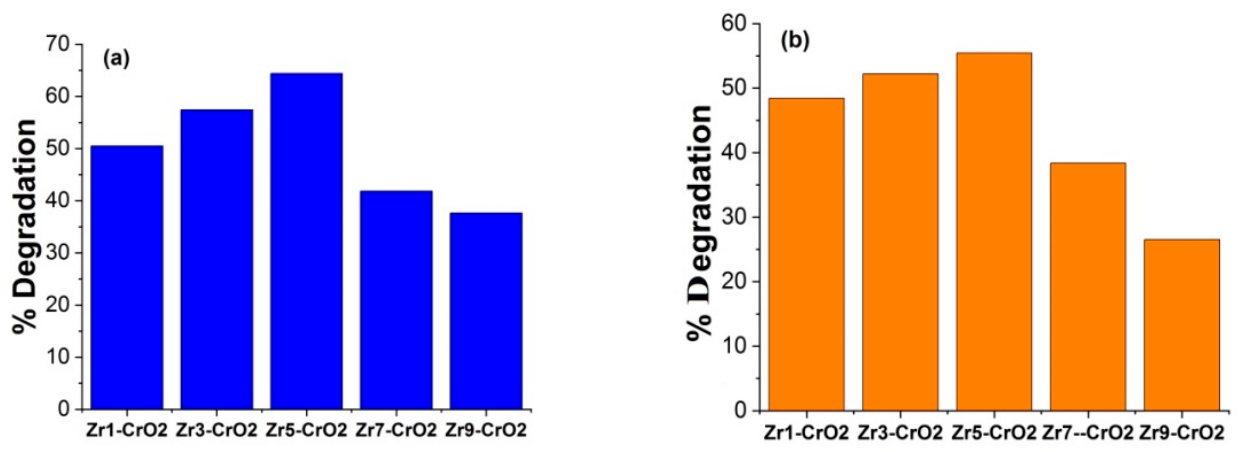

Figure 11. (a) Methylene blue (b) Methyl orange percent degradation at $140 \mathrm{~min}$.

\section{Tentative Mechanism}

The proposed mechanisms of $\mathrm{Zr}$-doped $\mathrm{CrO}_{2}$ nanoparticles for the degradation of $\mathrm{MB}$ and MO dyes are as follows:

i. After illumination with UV light, the electrons move from the conduction band to the valence band, leaving a positive hole in the valence band.

$$
\mathrm{CrO}_{2}+\mathrm{hv} \rightarrow \mathrm{CrO}_{2}\left(\mathrm{~h}^{+} \mathrm{vb}\right)+\mathrm{CrO}_{2}\left(\mathrm{e}^{-} \mathrm{cb}\right)
$$

ii. The electrons in the conduction band of $\mathrm{Zr}$-doped $\mathrm{CrO}_{2}$ can be trapped by dopant $\mathrm{Zr}^{4+}$, thereby holding up the recombination process of electrons.

$$
\mathrm{CrO}_{2}\left(\mathrm{e}^{-}\right)+\mathrm{Zr}^{4+} \rightarrow \mathrm{CrO}_{2}+\mathrm{Zr}^{3+} \text { (unstable) }
$$

iii. The trapped electrons $\left(\mathrm{Zr}^{4+} \rightarrow \mathrm{Zr}^{3+}\right)$ were scavenged by molecular oxygen, which is adsorbed on the surface of $\mathrm{CrO}_{2}$ to generate superoxide radicals, in turn producing hydrogen peroxide $\left(\mathrm{H}_{2} \mathrm{O}_{2}\right)$, hydroperoxyl $\left(\mathrm{HO}_{2}{ }^{\bullet}\right)$, and hydroxyl $\left({ }^{\bullet} \mathrm{OH}\right)$ radicals.

$$
\begin{gathered}
\mathrm{CrO}_{2}\left(\mathrm{e}^{-}\right)+\mathrm{O}_{2} \rightarrow \mathrm{CrO}_{2}+\mathrm{O}_{2}^{\bullet-} \\
\mathrm{CrO}_{2}\left(\mathrm{e}^{-}\right)+\mathrm{O}_{2}^{\bullet-}+\mathrm{H}_{2} \mathrm{O} \rightarrow \mathrm{CrO}_{2}+\mathrm{HO}_{2}^{\bullet}+\mathrm{HO}^{-} \\
\mathrm{CrO}_{2}\left(\mathrm{e}^{-}\right)+\mathrm{HO}^{\bullet}+\mathrm{H}^{+} \rightarrow \mathrm{CrO}_{2}+\mathrm{H}_{2} \mathrm{O}_{2} \\
\mathrm{CrO}_{2}\left(\mathrm{e}^{-}\right)+\mathrm{H}_{2} \mathrm{O}_{2} \rightarrow \mathrm{CrO}_{2}+\mathrm{HO}_{2}^{\bullet}+\mathrm{HO}^{-}
\end{gathered}
$$

iv. Finally, the holes act as oxidizing agents and electrons act as reducing agents for the degradation of $\mathrm{MB}$ and $\mathrm{MO}$ dyes in aqueous solution.

$$
\bullet \mathrm{OH}(\mathrm{hv})+\text { Pollutant } \rightarrow \text { Degradation product }
$$

\section{Materials and Methods}

\subsection{Materials}

The chemicals used for the preparation of zirconium-doped, chromium IV oxide photocatalysts were of analytical grade, and used as such without further purification. Zirconium metal powder, $\mathrm{CrO}_{2}$ powder, DI water, methylene blue, and methyl orange were purchased from Merck Ltd. (Darmstadt, Germany). Ethanol was purchased from Sigma-Aldrich (St. Louis, MO, USA).

\subsection{Synthesis of $\mathrm{Zr} / \mathrm{CrO}_{2}$ Photocatalyst by Solid-State Reaction Method}

Zirconium-doped, chromium IV oxide photocatalysts $\left(\mathrm{Zr} / \mathrm{CrO}_{2}\right)$ were prepared by a solid-state, environmentally friendly reaction at room temperature. Zirconium metal powder and chromium IV oxide powder were mixed in definite molar ratios (1:1, 3:1, 5:1, 7:1, and 9:1) using a mortar and pestle with a small amount of ethanol, and ground for several minutes until the powder was sufficiently mixed. After mixing, the prepared 
photocatalysts were calcined at $450{ }^{\circ} \mathrm{C}$ in a muffle furnace for $1 \mathrm{~h}$ to remove any impurities. The prepared photocatalysts were then characterized by various techniques, i.e., $\mathrm{XRD}$, SEM, EDX, FT-IR, UV-Vis, and BET, and were used for the degradation of methylene blue and methyl orange as such. Degradation studies were carried out by UV/Visible spectrophotometer (Perkin Elmer lambda 35, Waltham, MA, USA).

\subsection{Photocatalytic Experiments}

The photocatalytic activity was examined by dissolving $0.2 \mathrm{~g}$ of each catalyst (solid), i.e., $\mathrm{Zr} 1 \mathrm{CrO}_{2}, \mathrm{Zr} 3 \mathrm{CrO}_{2}, \mathrm{Zr} 5 \mathrm{CrO}_{2}, \mathrm{Zr}_{\mathrm{CrO}}$, and $\mathrm{Zr} 9 \mathrm{CrO}_{2}$, in $50 \mathrm{~mL}$ aqueous solution of $\mathrm{MB}$ and $\mathrm{MO}$ dyes (10 ppm). The reaction vessel was placed in the dark for complete desorption and adsorption equilibrium for $20 \mathrm{~min}$ with continuous stirring. Zero-time readings were taken before the samples were placed under UV light (10 watt) at $15 \mathrm{~cm}$ distance for maximum utilization of the light at different intervals of time (10-140 $\mathrm{min}$ ) for their complete mineralization. Afterwards, all samples were filtered through a $0.45 \mu \mathrm{m}$ (PVDF) filter and then analyzed using a UV/Visible spectrophotometer (Carry 50) to determine the degradation, reaction kinetics, and concentration.

\section{Conclusions}

$\mathrm{Zr}$-doped $\mathrm{CrO}_{2}$ nanoparticles were prepared on the basis of different concentrations of dopant $(\mathrm{Zr})$ through a one-step, solid-state reaction method. XRD analysis confirmed the doping of $\mathrm{Zr}$ in $\mathrm{CrO}_{2}$ by replacing the $\mathrm{Cr}$ with $\mathrm{Zr}$. This optical study verifies that as the dopant concentration increases, the absorbance peaks shifts to higher wavelengths and lower energy as a result of the decreasing band gap of the host material. Moreover, other techniques such as FT-IR and EDX confirmed the $\mathrm{Zr}$ doping in $\mathrm{CrO}_{2}$, which shows that the photocatalysts are suitable for UV light absorption due to the reduction in the band gap. It was also observed that as the concentration of dopant increases, the photocatalytic efficiency of the catalysts also increases up to $5 \mathrm{wt}$.\%. Therefore, $\mathrm{Zr}$-doped $\mathrm{CrO}_{2}$ photocatalysts could potentially be used for wastewater treatment.

Author Contributions: Conceptualization, Z.M. and M.B.; data curation, F.A., M.S. and N.A.; formal analysis, M.R.S., S.F.A., M.A.F.S. and E.M.A.; funding acquisition, M.R.S.; investigation, Z.M., F.A., M.S., N.A. and M.B.; methodology, A Z.M. and M.B.; visualization, M.R.S.; writing-original draft, Z.M., F.A., M.S., N.A. and M.B.; writing-review and editing, Z.M., F.A., M.S., N.A., M.B., M.R.S., S.F.A. and M.K.; All authors have read and agreed to the published version of the manuscript.

Funding: The authors extend their appreciation to the Deanship of Scientific Research at King Saud University for funding this work through Research Group no. RG-1441-453.

Institutional Review Board Statement: Not applicable.

Informed Consent Statement: Not applicable.

Data Availability Statement: Data is contained within the article.

Acknowledgments: The authors extend their appreciation to the Deanship of Scientific Research at King Saud University for funding this work through Research Group no. RG-1441-453. The authors also thankful to department of Physics, Kohat University of Science and Technology, Pakistan for its co-operation by providing synthesis and characterization facility at the nanotech lab for the synthesized material.

Conflicts of Interest: The authors declare that they have no conflicts of interest.

\section{References}

1. Tang, A.Y.L.; Lo, C.K.Y.; Kan, C.-W. Textile dyes and human health: A systematic and citation network analysis review. Coloration Technol. 2018, 134, 245-257. [CrossRef]

2. Katheresan, V.; Kansedo, J.; Lau, S.Y. Efficiency of various recent wastewater dye removal methods: A review. J. Environ. Chem. Eng. 2018, 6, 4676-4697. [CrossRef]

3. Azbar, N.; Yonar, T.; Kestioglu, K. Comparison of various advanced oxidation processes and chemical treatment methods for COD and color removal from a polyester and acetate fiber dyeing effluent. Chemosphere 2004, 55, 35-43. [CrossRef] [PubMed] 
4. Ibhadon, A.O.; Fitzpatrick, P. Heterogeneous Photocatalysis: Recent Advances and Applications. Catalysts 2013, 3, 189-218. [CrossRef]

5. Nagajyothi, P.C.; Prabhakar Vattikuti, S.V.; Devarayapalli, K.C.; Yoo, K.; Shim, J.; Sreekanth, T. Green synthesis: Photocatalytic degradation of textile dyes using metal and metal oxide nanoparticles-latest trends and advancements. Crit. Rev. Environ. Sci. Technol. 2020, 50, 2617-2723. [CrossRef]

6. Huang, S.; Wu, X.; Niu, J.; Qin, S. Structural, magnetic and electronic properties of $\mathrm{CrO}_{2}$ at multimegabar pressures. RSC Adv. 2018, 8, 24561-24570. [CrossRef]

7. Verma, V.; Ahmad, S.; Dar, A.; Kotnala, R. An Inexpensive Route to Synthesize High-Purity CrO. ISRN Mater. Sci. 2012 , 2012. [CrossRef]

8. Zhang, Z.; Cheng, M.; Lu, Z.; Yu, Z.; Liu, S.; Liang, R.; Liu, Y.; Shi, J.; Xiong, R. Magnetic properties and thermal stability of Ti-doped CrO2 films. J. Magn. Magn. Mater. 2018, 451, 572-576. [CrossRef]

9. Chamberland, B.L. The chemical and physical properties of $\mathrm{CrO} 2$ and tetravalent chromium oxide derivatives. Crit. Rev. Solid State Mater. Sci. 1977, 7, 1-31. [CrossRef]

10. Larbi, T.; Amara, M.; Ouni, B.; Amlouk, M. Enhanced photocatalytic degradation of methylene blue dye under UV-sunlight irradiation by cesium doped chromium oxide thin films. Mater. Res. Bull. 2017, 95, 152-162. [CrossRef]

11. Ireland, C.; Bennett, S.C.; Darwent, J.R.; Palgrave, R.G.; Smith, A.W.J.; Claridge, J.B.; Poulston, S.; Clark, J.H.; Rosseinsky, M.J. Visible light photocatalysis by metal-to-metal charge transfer for degradation of methyl orange. J. Mater. Chem. A 2016, 4, 12479-12486. [CrossRef]

12. Biswas, S. Correlation-induced charge ordering in the metal-insulator transition of Ru-doped tetragonal CrO2. Mater. Sci. Eng. B 2018, 238, 100-107. [CrossRef]

13. Ding, Y.; Yuan, C.; Wang, Z.; Liu, S.; Shi, J.; Xiong, R.; Yin, D.; Lu, Z. Improving thermostability of CrO2 thin films by doping with Sn. Appl. Phys. Lett. 2014, 105, 092401. [CrossRef]

14. Yuan, C.; Lu, Z.; Liu, S.; Gan, Z.; Guo, F.; Xiong, R.; Mei, X.; Liu, H.; Shi, J. Half metallicity and magnetic properties of $\mathrm{CrO}_{2}$ doped with Ti, Sn or Ru. J. Magn. Magn. Mater. 2016, 417, 80-86. [CrossRef]

15. Mataré, H.F. Defect Electronics in Semiconductors; Wiley-Interscience: New York, NY, USA, 1971.

16. Khan, M.A.M.; Khan, W.; Khan, M.N.; Alhazaa, A.N. Enhanced visible light-driven photocatalytic performance of Zr doped $\mathrm{CeO}_{2}$ nanoparticles. J. Mater. Sci. Mater. Electron. 2019, 30, 8291-8300. [CrossRef]

17. Meshesha, D.S.; Matangi, R.C.; Tirukkovalluri, S.R.; Bojja, S. Synthesis, characterization and visible light photocatalytic activity of $\mathrm{Mg} 2+$ and $\mathrm{Zr} 4+$ co-doped TiO2 nanomaterial for degradation of methylene blue. J. Asian Ceram. Soc. 2017, 5, 136-143. [CrossRef]

18. Subash, B.; Krishnakumar, B.; Swaminathan, M.; Shanthi, M. Highly efficient, solar active, and reusable photocatalyst: Zr-loaded Ag-ZnO for reactive red 120 dye degradation with synergistic effect and dye-sensitized mechanism. Langmuir 2013, 29, 939-949. [CrossRef]

19. Basahel, S.N.; Ali, T.T.; Mokhtar, M.; Narasimharao, K. Influence of crystal structure of nanosized $\mathrm{ZrO}_{2}$ on photocatalytic degradation of methyl orange. Nanoscale Res. Lett. 2015, 10, 73. [CrossRef] [PubMed]

20. Kumar, S.; Ojha, A.K. Oxygen vacancy induced photoluminescence properties and enhanced photocatalytic activity of ferromagnetic $\mathrm{ZrO} 2$ nanostructures on methylene blue dye under ultra-violet radiation. J. Alloys Compd. 2015, 644, 654-662. [CrossRef]

21. Koirala, R.; Gunugunuri, K.R.; Pratsinis, S.E.; Smirniotis, P.G. Effect of zirconia doping on the structure and stability of CaO-based sorbents for $\mathrm{CO}_{2}$ capture during extended operating cycles. J. Phys. Chem. C 2011, 115, 24804-24812. [CrossRef]

22. Jung, K.T.; Bell, A.T. An in Situ Infrared Study of Dimethyl Carbonate Synthesis from Carbon Dioxide and Methanol over Zirconia. J. Catal. 2001, 204, 339-347. [CrossRef]

23. Tseng, T.K.; Lin, Y.S.; Chen, Y.J.; Chu, H. A review of photocatalysts prepared by sol-gel method for VOCs removal. Int. J. Mol. Sci. 2010, 11, 2336-2361. [CrossRef] [PubMed]

24. Somraksa, W.; Suwanboon, S.; Amornpitoksuk, P.; Randorn, C. Physical and Photocatalytic Properties of $\mathrm{CeO}_{2} / \mathrm{ZnO} / \mathrm{ZnAl}_{2} \mathrm{O}_{4}$ Ternary Nanocomposite Prepared by Co-precipitation Method. Mater. Res. 2020, 23. [CrossRef]

25. Bao, X.-W.; Yan, S.-S.; Chen, F.; Zhang, J. Preparation of TiO2 photocatalyst by hydrothermal method from aqueous peroxotitanium acid gel. Mater. Lett. 2005, 59, 412-415. [CrossRef]

26. Colmenares, J.C.; Kuna, E.; Lisowski, P. Synthesis of photoactive materials by sonication: Application in photocatalysis and solar cells. In Sonochemistry; Springer: Berlin/Heidelberg, Germany, 2017; pp. 95-115.

27. Ye, M.; Pan, J.; Guo, Z.; Liu, X.; Chen, Y. Effect of ball milling process on the photocatalytic performance of $\mathrm{CdS}_{\mathrm{STO}} \mathrm{Composite}$. Nanotechnol. Rev. 2020, 9, 558-567. [CrossRef]

28. Stark, W.J.; Maciejewski, M.; Mädler, L.; Pratsinis, S.E.; Baiker, A. Flame-made nanocrystalline ceria/zirconia: Structural properties and dynamic oxygen exchange capacity. J. Catal. 2003, 220, 35-43. [CrossRef]

29. $\mathrm{Hu}$, J.; Cao, Y.; Wang, K.; Jia, D. Green solid-state synthesis and photocatalytic hydrogen production activity of anatase $\mathrm{TiO}_{2}$ nanoplates with super heat-stability. RSC Adv. 2017, 7, 11827-11833. [CrossRef]

30. Singh, G.; Ram, S.; Eckert, J.; Fecht, H. Synthesis and morphological stability in $\mathrm{CrO}_{2}$ single crystals of a half-metallic ferromagnetic compound. J. Phys. Conf. Ser. 2009, 144, 012110. [CrossRef]

31. Khan, M.A.M.; Khan, W.; Khan, M.N.; Alhazaa, A.N. Microstructural properties and enhanced photocatalytic performance of Zn doped $\mathrm{CeO}_{2}$ nanocrystals OPEN. J. Nat. Res. 2017. [CrossRef] 
32. Jansons, A.W.; Koskela, K.M.; Crockett, B.M.; Hutchison, J.E. Transition metal-doped metal oxide nanocrystals: Efficient substitutional doping through a continuous growth process. Chem. Mater. 2017, 29, 8167-8176. [CrossRef]

33. Singh, D.K.; Pandey, D.K.; Yadav, R.R.; Singh, D. Characterization of $\mathrm{CrO}_{2}$-poly-vinyl pyrrolidone magnetic nanofluid. J. Magn . Magn. Mater. 2012, 324, 3662-3667. [CrossRef]

34. Bhati, I.; Punjabi, P.B.; Ameta, S.C. Photocatalytic degradation of fast green using nanosized $\mathrm{CeCrO}_{3}$. Maced. J. Chem. Chem. Eng. 2010, 29, 195-202. [CrossRef]

35. Ibrahim, M.; Alaam, M.; El-Haes, H.; Jalbout, A.F.; de Leon, A. Analysis of the structure and vibrational spectra of glucose and fructose. Eclet. Quim. 2006, 31, 15-21. [CrossRef]

36. Chertihin, G.V.; Bare, W.D.; Andrews, L. Reactions of laser-ablated chromium atoms with dioxygen. Infrared spectra of CrO, $\mathrm{OCrO}, \mathrm{CrOO}, \mathrm{CrO}_{3}, \mathrm{Cr}(\mathrm{OO})_{2}, \mathrm{Cr}_{2} \mathrm{O}_{2}, \mathrm{Cr}_{2} \mathrm{O}_{3}$ and $\mathrm{Cr}_{2} \mathrm{O}_{4}$ in solid argon. J. Chem. Phys. 1997, 107, 2798-2806. [CrossRef]

37. Lim, G.; Minami, K.; Yamamoto, K.; Sugihara, M.; Uchiyama, M.; Esashi, M. Multi-link active catheter snake-like motion. Robotica 1996, 14, 499-506. [CrossRef]

38. Ca, N.X.; Van, H.T.; Do, P.V.; Thanh, L.D.; Tan, P.M.; Truong, N.X.; Oanh, V.T.K.; Binh, N.T.; Hien, N.T. Influence of precursor ratio and dopant concentration on the structure and optical properties of $\mathrm{Cu}$-doped ZnCdSe-alloyed quantum dots. RSC Adv. 2020, 10, 25618-25628. [CrossRef]

39. Davis, E.A.; Mott, N.F. Conduction in non-crystalline systems V. Conductivity, optical absorption and photoconductivity in amorphous semiconductors. Philos. Mag. 1970, 22, 903-922. [CrossRef]

40. Tauc, J.; Grigorovici, R.; Vancu, A. Optical properties and electronic structure of amorphous germanium. Phys. Status Solidi B 1966, 15, 627-637. [CrossRef]

41. Mott, N.F.; Davis, E.A. Electronic Processes in Non-Crystalline Materials; Oxford University Press: New York, NY, USA, 1971.

42. El-Molla, S.A.; Ibrahim, S.M.; Ebrahim, M.M. Influence of $\mathrm{ZnO}$ doping and calcination temperature of nanosized CuO/MgO system on the dehydrogenation reactions of methanol. Int. J. Ind. Chem. 2016, 7, 223-229. [CrossRef]

43. Huang, F.; Yan, A.; Zhao, H. Influences of doping on photocatalytic properties of $\mathrm{TiO}_{2}$ photocatalyst. In Semiconductor Photocatalysis-Materials, Mechanisms and Applications; Cao, W., Ed.; IntechOpen: Rijeka, Croatia, 2016; pp. 31-80.

44. Akpan, U.; Hameed, B. Parameters affecting the photocatalytic degradation of dyes using $\mathrm{TiO}_{2}$-based photocatalysts: A review. J. Hazard. Mater. 2009, 170, 520-529. [CrossRef]

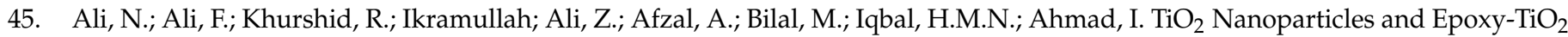
Nanocomposites: A Review of Synthesis, Modification Strategies, and Photocatalytic Potentialities. J. Inorg. Organomet. Polym. Mater. 2020, 30, 4829-4846. [CrossRef]

46. Daneshvar, N.; Salari, D.; Niaei, A.; Khataee, A. Photocatalytic degradation of the herbicide erioglaucine in the presence of nanosized titanium dioxide: Comparison and modeling of reaction kinetics. J. Environ. Sci. Health Part B 2006, 41, 1273-1290. [CrossRef] [PubMed]

47. Ali, N.; Ali, F.; Said, A.; Begum, T.; Bilal, M.; Rab, A.; Sheikh, Z.A.; Iqbal, H.M.N.; Ahmad, I. Characterization and Deployment of Surface-Engineered Cobalt Ferrite Nanospheres as Photocatalyst for Highly Efficient Remediation of Alizarin Red S Dye from Aqueous Solution. J. Inorg. Organomet. Polym. Mater. 2020, 30, 5063-5073. [CrossRef]

48. Zheng, S.; Jiang, W.; Cai, Y.; Dionysiou, D.D.; O'Shea, K.E. Adsorption and photocatalytic degradation of aromatic organoarsenic compounds in $\mathrm{TiO}_{2}$ suspension. Catal. Today 2014, 224, 83-88. [CrossRef]

49. Ali, N.; Ali, F.; Ullah, I.; Ali, Z.; Duclaux, L.; Reinert, L.; Lévêque, J.M.; Farooq, A.; Bilal, M.; Ahmad, I. Organically modified micronsized vermiculite and silica for efficient removal of Alizarin Red S dye pollutant from aqueous solution. Environ. Technol. Innov. 2020, 19, 101001. [CrossRef] 